\title{
The pattern and determinants of US foreign direct investment in industrialised countries
}

Citation for published version (APA):

Narula, R., \& Wakelin, K. (1997). The pattern and determinants of US foreign direct investment in industrialised countries. MERIT, Maastricht Economic Research Institute on Innovation and Technology. MERIT Research Memoranda No. 001 https://doi.org/10.26481/umamer.1997001

Document status and date:

Published: 01/01/1997

DOI:

10.26481/umamer.1997001

Document Version:

Publisher's PDF, also known as Version of record

\section{Please check the document version of this publication:}

- A submitted manuscript is the version of the article upon submission and before peer-review. There can be important differences between the submitted version and the official published version of record.

People interested in the research are advised to contact the author for the final version of the publication, or visit the DOI to the publisher's website.

- The final author version and the galley proof are versions of the publication after peer review.

- The final published version features the final layout of the paper including the volume, issue and page numbers.

Link to publication

\footnotetext{
General rights rights.

- You may freely distribute the URL identifying the publication in the public portal. please follow below link for the End User Agreement:

www.umlib.nl/taverne-license

Take down policy

If you believe that this document breaches copyright please contact us at:

repository@maastrichtuniversity.nl

providing details and we will investigate your claim.
}

Copyright and moral rights for the publications made accessible in the public portal are retained by the authors and/or other copyright owners and it is a condition of accessing publications that users recognise and abide by the legal requirements associated with these

- Users may download and print one copy of any publication from the public portal for the purpose of private study or research.

- You may not further distribute the material or use it for any profit-making activity or commercial gain

If the publication is distributed under the terms of Article $25 \mathrm{fa}$ of the Dutch Copyright Act, indicated by the "Taverne" license above, 


\title{
The Pattern and Determinants of US Foreign Direct Investment in Industrialised Countries
}

\author{
By \\ Rajneesh Narula and Katharine Wakelin
}

\author{
MERIT \\ Maastricht University \\ P.O. Box 616 \\ 6200 MD Maastricht \\ The Netherlands \\ Tel: $+31433883823 / 86$ \\ Fax: +31433216518 \\ r.narula@mw.unimaas.nl \\ k.wakelin@merit.unimaas.nl
}

This paper is funded under the project entitled 'Technology, Economic Integration and Social Cohesion', part of the TSER programme financed by the European Commission. It can be found online at: http://meritbbs.unimaas.nl/tser/tser.html 


\section{Introduction}

Despite the growth of outward foreign direct investment (FDI) from Japan and some European countries, the United States still has the largest stock of overseas direct investment in the world. In 1993 that stock was worth approximately $\$ 549$ billion, $\$ 126$ billion more than Japan's outward investment, and over double that of the UK. Direct investment undertaken by US multinationals is therefore an important characteristic not only of the US economy, but also of the world economy. Due to the scale of multinational activity in the world economy, the level and location of FDI is of interest both to the countries which undertake FDI (the home country), and the country in which the FDI is located (the host country). National-level policy makers give incentives to multinational enterprises (MNEs) to locate in their country, as FDI can create employment and wealth in the host country, and improve the balance of payments through exports. Conversely, there are concerns in countries which undertake a large amount of FDI, that production is being transferred overseas which will have a detrimental effect on domestic employment, wealth and exports.

The main aim of this paper is to analyse the factors which determine the level of US direct investment in other industrialised countries. An econometric model of the determinants of FDI will be applied to US direct investment in the manufacturing sectors of seven major industrialised countries; together they account for $45 \%$ of US manufacturing investment overseas. The model estimated is based on a number of determinants including both the characteristics of the home country (the US) and of the host country. Understanding the determinants of FDI in industrialised countries is an important contribution to the policy debate over 'competitiveness'. The competitiveness debate has two perspectives which are strongly inter-related. First, there is the concern expressed by policy makers over the continuing competitiveness of firms on an international basis, and second, there is concern over the competitiveness of locations. Many industrialised countries compete in giving particular tax and other fiscal incentives to attract MNEs. More broadly, and perhaps with greater economic implications, attracting foreign capital through low wages and flexible working conditions has also become part of many countries' economic policy, and is articulated as a concern over competitiveness. In addition, those countries which have a rising level of outward FDI (such as Germany), are concerned that it is the lack of competitiveness of the domestic economy which is the cause.

While the direct effects of undertaking FDI may be considerable in terms of employment, and capital availability, the impact of FDI on the export behaviour of the home country is also of importance to the home country. In the case that FDI substitutes for exports, FDI 
is seen as a divergence of resources away from the domestic market. Production is being relocated to a foreign market which may have considerable welfare implications for the home country. However, recent empirical studies have suggested that there may be a complementary relationship between FDI and exports (Hufbauer et al. 1994, Veugelers, 1991 and Pfaffermayr, 1996, for Austria) which has positive welfare implications for the home country with FDI raising exports and hence production in the home country. This paper includes lagged exports as a determinant of outward FDI in order to investigate if outward FDI and exports have been complements or substitutes over the period considered, and if this relationship is the same for all destination countries. FDI and exports are also interlinked in the sense that exports normally precede FDI, with the firm 'learning' about overseas market opportunities initially through exports before engaging in FDI.

One objective of the analysis is to test if the determinants of US outward investment vary according to the country of destination or, if a common model can be applied to all US outward investment regardless of the destination country. The result will depend on the reasons for undertaking US investment in the host country. In some cases FDI may be aimed at taking advantage of natural resources, or low relative costs, while for other locations the skills and technology available in the host country may be the main motivating factor behind direct investment. As the sample of countries used in this paper consists of seven industrialised countries - France, Germany, Italy, Japan, the Netherlands, Sweden and the UK - it is possible that there will be similar motives for undertaking FDI in these countries; although there is still considerable variation in terms of size, the availability of natural resources, and the level of technology of countries within the sample. Clearly, if the determinants of FDI vary between countries, then the policies undertaken by national governments to attract FDI need to take account of these differences.

Many previous analyses of the determinants of FDI have taken a static framework, looking at the determinants of FDI in a cross-section (Narula and Wakelin, 1995). Taking a cross-section implicitly assumes that the relationship being studied is in equilibrium at that time. This study differs from static analyses in allowing for dynamic affects over time. The analysis considers total FDI in the manufacturing sector and thus abstracts from differences between sectors. This aggregate approach allows an assessment to be made for the whole of manufacturing. For instance, while trade and FDI may substitute for each other in some sectors, this may be compensated for by them complementing each other in other sectors. This paper also differs from other studies in stressing the role of differences in technology as a determinant of FDI, a factor which has been neglected in many studies. 
The paper is set out as follows. Section Two provides some descriptive statistics on the role of MNE activity in the world economy and the significance of US FDI to both host and home economies. Section Three outlines the empirical evidence relating to the determinants of outward FDI for industrialised countries. Section Four presents the empirical model, while Section Five gives the results of the model and compares them to earlier results. Section six gives a brief summary and some conclusions.

\section{Growth of MNE activity and the significance of US FDI}

One of the most distinctive features of the post-war era has been the increasing significance of multinational firms in the world economy. The growth of overseas production by MNEs through foreign direct investment has been reported to be growing faster than either trade or GDP since the mid 1970s. Indeed, UNCTAD (1996) estimates that in 1995 the sales of foreign affiliates of MNEs were US\$ 6022 million while the total exports of goods and services by all firms worldwide was only US\$ 4707 million. In addition, as much as $80 \%$ of world exports are conducted by MNEs.

As background for the later econometric analysis Table 1 gives some details of the role of MNE activity in the sample of countries included in the analysis. Summary data are also included for all other countries divided into developed and developing countries. The data presented are for two years - 1973 and 1993 -which span the period under consideration. The level of MNE activity has grown for all the countries in the sample, and in certain countries (the UK and the Netherlands) accounts for at least half of GDP by 1993. The rapid increase in FDI since the 1970s has also been connected with the phenomenon known as 'globalisation', a term that loosely describes the increasing homogeneity of income, technology and consumption patterns across the industrialised countries. Indeed, the industrialised countries continue to be not only the primary source of the outward FDI (responsible for almost $95 \%$ of all outward FDI), they are also the primary host locations for much of this activity (accounting for about $75 \%$ of inward FDI). In general, most firms from industrialised countries have tended to focus their overseas investments in other industrialised economies, rather than developing countries.

The growth and prominence of the activities of US MNEs illustrate these trends. In the immediate post-war period US MNEs enjoyed a technological and economic hegemony, partly due to the fact that the US emerged from the war with its infrastructure and industry not only intact, but strengthened, in contrast to the rest of the industrialised world. The high cost of capital in the US, the lack of liquidity in the rest of the world, and the low competitive advantages of many competitors, led to a rapid growth of US FDI activity (Hagedoorn and Narula 1996). By 1960, US MNEs accounted for $48.3 \%$ of total 
worldwide FDI stocks. In fact, the US continued to account for almost half of all FDI stocks till the early 1970s, although by this time many industrialised countries had experienced a period of technological and economic convergence. Subsequently, the US share of world FDI began to fall, and by 1993 was just above $25 \%$.

A number of features of US FDI in the sample countries can be seen from Table 1:

1. The concentration of US FDI in the industrialised economies has stayed relatively constant over this period, although within the sample of countries there has been a strong surge of FDI into the UK. By 1993 almost a fifth of all US outward FDI was concentrated in the UK, more than in any other single country. Shares of US FDI did not show substantial change in any other country in the sample except Japan, where it has doubled over the 20 years.

\section{Table 1: Indicators of FDI in the sample countries}

\begin{tabular}{|c|c|c|c|c|c|c|c|c|c|c|}
\hline & $\begin{array}{c}\text { MNEs share } \\
\text { of GDP }\end{array}$ & & $\begin{array}{l}\% \text { share } \\
\text { of total US } \\
\text { worldwide FDI }\end{array}$ & & $\begin{array}{l}\% \text { of inward } \\
\text { FDI stock of } \\
\text { by US firms }\end{array}$ & ost owned & $\begin{array}{l}\text { S mfg I } \\
\text { US FD }\end{array}$ & & $\begin{array}{l}\% \text { distribution } \\
\text { mfg FDI stocl }\end{array}$ & $\begin{array}{l}\text { US } \\
\text { country }\end{array}$ \\
\hline & 1973 & 1993 & 1973 & 1993 & 1973 & 1993 & 1973 & 1993 & 1973 & 1993 \\
\hline Germany & 7.2 & 16.4 & 7.6 & 6.6 & 58.4 & 28.8 & 58.1 & 56.5 & 10.0 & 10.7 \\
\hline France & 7.7 & 22.8 & 4.2 & 4.3 & 47.2 & 19.4 & 68.5 & 52.5 & 6.6 & 6.6 \\
\hline UK & 22.9 & 54.9 & 10.9 & 18.6 & 45.8 & 53.0 & 59.9 & 23.3 & 14.9 & 12.5 \\
\hline Netherlands & 39.1 & 71.9 & 2.3 & 3.7 & 29.4 & 23.9 & 52.4 & 37.5 & 2.8 & 4.0 \\
\hline Italy & 9.2 & 12.7 & 2.2 & 2.3 & 22.1 & 24.3 & 62.9 & 58.0 & 3.1 & 3.8 \\
\hline Sweden & 8.1 & 34.5 & 0.8 & 0.4 & 78.1 & 18.8 & 49.9 & 50.2 & 1.0 & 0.6 \\
\hline Total & & & 28.0 & 36.0 & 43.7 & 33.4 & 67.0 & 37.9 & 42.9 & 39.3 \\
\hline Japan & 2.9 & $8-10 \%$ & 2.6 & 5.6 & $15-20 \%$ & $20-25 \%$ & 52.4 & 43.0 & 3.2 & 6.9 \\
\hline USA & 9.3 & 16.1 & & & & & & & & \\
\hline Other developed & NA & NA & 43.2 & 30.7 & NA & NA & 40.0 & 43.7 & 39.5 & 38.6 \\
\hline Total developed & NA & 20.9 & 71.3 & 72.2 & 47.0 & 25.8 & 50.6 & 37.4 & 82.4 & 77.9 \\
\hline developing & 5.9 & 14.2 & 22.6 & 27.8 & 41.9 & 30.2 & 34.1 & 27.7 & 17.6 & 22.1 \\
\hline TOTAL & 8.3 & 19.5 & 100.0 & 100.0 & NA & NA & 43.8 & 34.7 & 100.0 & 100.0 \\
\hline
\end{tabular}

2. The role of US MNEs in the total inward FDI stocks of these countries continues to be significant. Despite its decline since the early 1970s US MNEs account for approximately a quarter of inward FDI stocks in the developed countries. This suggests that, given the vintage of US investments relative to that by MNEs of other nationalities, US MNEs probably account for at least $10 \%$ of the GDP of most of these countries. Nevertheless, 
large drops in the proportion of FDI owned by US firms have been seen in some countries, notably Sweden, but also to a lesser extent France and Germany.

3. Much of the growth of US FDI has been in the tertiary sector, reflecting the increasing importance of services in the advanced economies, as well as the growing liberalisation of regulatory restrictions on foreign participation in service sectors. The surge in FDI to the UK during this period seems to have taken place entirely in non-manufacturing. Overall, in the countries mentioned in Table 1, the manufacturing sector accounted for well over 50\% of US FDI stocks in 1973. By 1993, with the exception of Sweden, Italy and Germany where their has been only a marginal change, there seems to be have been a considerable drop in the relative importance of manufacturing FDI by US firms in all countries, even in the developing countries where one might have expected the relative costs of production might have favoured FDI in manufacturing to exploit wage rate differentials. The large fall in the proportion of FDI in Sweden owned by US firms noted in point (3) is entirely accounted for by changes in non-manufacturing FDI.

4. Despite the higher factor costs associated with the industrialised countries, just over $75 \%$ of US FDI in manufacturing continues to be invested there, although there has been a small fall. Casual observation would suggest that US manufacturing FDI has become increasingly concentrated in the higher wage countries, with the share of US manufacturing FDI in Japan, Italy and the Netherlands growing in importance. In contrast, the UK, which has one of the lowest labour costs in Europe, has seen a decline in its share of US manufacturing FDI.

\section{The Determinants of US FDI}

Although there is a large literature on the determinants of FDI, several reviews of the literature already exist (for instance Agarwal 1980, Dunning, 1993 and Caves, 1996), and it is not the objective of this section to discuss them. Instead, this section focuses on the theory underlining the model estimated in Section 4. The primary features of the current paper, in contrast to other work on the determinants of US FDI, include the use of a dynamic time series model instead of a static framework, and the incorporation of technological variables into the model. The current research is conducted on US FDI in several industrialised countries on a bilateral basis. The majority of empirical studies has used cross-sectional techniques, and has generally tended to focus on US FDI in Europe.

A number of time-series studies has been conducted on US FDI, including those by Scaperlanda and Mauer (1969), Lunn (1980, 1983), Scaperlanda and Balough (1983), and more recently Barrell and Pain (1996). A particular area of interest has been the impact of the growth and formation of the European single market on US FDI, including the 
changes in structural impediments over time (see Clegg, 1996) ${ }^{1}$. Our analysis tests a broader set of hypotheses about US outward FDI, with particular emphasis on the role of differences in technology in influencing the pattern of US FDI.

First, the paper focuses on understanding the advantages of the host country relative to the home country. It is well established that when overseas investment is undertaken, firms engage in the selection of a location based on the advantages of that location relative to those of the home country (Lall 1980). In other words, firms seek to internalise assets, or access to assets, which are not available, or not available as cheaply, in other locations. Such advantages have been defined as location advantages when they are available to all firms at a given location; when a singe firm has access to these assets, they are ownership advantages. A large number of studies analysing the location determinants of outward FDI tends to focus on the characteristics of the host country and the home country, rather than relative advantages. This preference stems from an understanding that there are both 'push' and 'pull' factors determining investment decisions. The significance of the two sets of factors is associated with the motive for undertaking investment abroad, and the industry in which the FDI takes place.

For instance, in the case of investment which aims to exploit resources, host country factors are generally more significant than those of the home country. Where investment is strategic in nature, for example aiming to benefit from large clusters of existing firms in a given location, the lack of ownership advantages of the home country may be the most important determinant. If the main motivation for FDI is to simply exploit markets, relative cost advantages and market size will be the primary determinants. In the present study we focus on US FDI in the manufacturing sector, which tends to be primarily market-seeking in nature. The host countries in our empirical exercise are other industrialised countries with relatively low levels of tariffs and non-tariff barriers (with the possible exception of Japan during the 1970s) during the period in question; as a result we can also rule out import-substituting investment as a substantial motive. Although we cannot rule out strategic behaviour, such as oligoplistic interaction (Knickerbocker, 1973), or strategic asset-acquiring investment (Dunning, 1993), which are characteristic of industrialised country firms, the current data set is not appropriate for investigating those issues, which need to be addressed at a firm level. We have also assumed, in the cases where we have used relative variables, that the primary choice facing the MNE is between the home and the host countries, and not a broader choice between two or more non-home country locations.

\footnotetext{
${ }^{1}$ Scaperlanda and Balough (1983) and more recently Barrell and Pain (1996) also tested the effect of the US capital control programme which attempted to limit the outflow of US direct investment capital between 1965 and 1972 .
} 
As has been emphasised by several recent studies of the growth of FDI, the relative importance of non-home country factors tends to increase over time. This is associated with two different issues. First, there is the question of whether any given investment represents sequential or initial investment (Kogut, 1983). Much of the investment activity covered by our empirical analysis if of the former type. The nature of ownership advantages enjoyed by a new entrant to a market tend to be different from those of an experienced investor ( $\mathrm{Yu}, 1990)$. The second issue is closely related to the first, and is associated with the extent of multinationality of the investing firm. The characteristics of the firm are determined by the national systems of innovation they operate within. Firms that are uninational in character are primarily formed by their home country national systems of innovation, while an MNE with a large share of total value added being conducted overseas will display characteristics that are determined by the national systems of several countries.

The second theme that deserves attention is the relative importance of country-specific determinants. As the competitive advantages of firms move towards more technologyintensive industries, which is the case with most of the countries in the sample, they become increasingly firm-specific, and less country-specific (Narula and Wakelin 1995). This weakening causality is not unrelated to the effects of increasing multinationality. Both country and firm specific advantages are outlined below.

\section{The competitiveness of locations: Location advantages}

a. Market and demand related variables. These focus on the role of demand conditions in the host markets, in terms of potential or actual demand, and their implications for economies of scale and scope. Within the context of US FDI in the EU, both absolute market size has been used, as well as increases in market size. With few exceptions both have been found to have a significant influence on US FDI into the EU as a whole. Barrell and Pain (1996) find a 1\% rise in the GNP of 7 major economies leads to an increase in the real investment stock of US FDI of $0.83 \%$. On a country-specific basis, most studies on FDI have found a strong influence of market size variables (Swedenborg 1979, Veugelers 1991).

b. Cost related factors. These relate to the costs of production, and include wage costs and transport costs. Empirical studies have found mixed results for cost variables, especially in the case of FDI between industrialised countries. Wage costs, both relative and absolute, have been found to have little significance in some studies, and in both Yamawaki (1991b) and Froot and Stein (1991) which refer to Japanese outward FDI in Europe and the US respectively, wages were a significant determinant, but had a positive 
rather than the expected negative effect. Barrell and Pain (1996) find that unit labour costs in the US are positively related to the level of outward investment, i.e. they are a relevant 'push' factor for FDI.

c. Financial explanations. It continues to be argued by many economists that much of what is tagged as direct investment simply represents movements of capital to exploit differentials in the cost of capital. Several arguments have been made along the lines that FDI represents movement of capital to exploit differences in the cost of capital as reflected by differences in exchange, tax and interests rates (Froot and Stein, 1991). Several studies have included financial variables, such as Culem (1988), but the results remain mixed, partly because the causality between FDI and financial variables is different in many contributions. A recent article by Kogut and Chang (1996), using firm level data on Japanese investment in the US suggests that real exchange rates are important, but only insofar as they determine the timing of entry. They find the primary determinant of entry to be the firm's ownership advantages and previous experience.

d. External relations. It is also important to consider the role of exports in FDI. There is a considerable literature on the growth of international activity of firms over time as a learning process, for instance Cantwell (1989). Indeed, numerous studies have observed that firms tend to enter a foreign market initially through exports before proceeding to FDI. Once initial investment is made, subsequent sequential investments tend to occur more frequently beyond a certain threshold (Yu 1990, Kogut and Chang 1996). As a result lagged FDI and/or exports are often included as proxies for experience.

The relationship between trade and FDI depends on the type of FDI taking place, for instance whether the MNE is vertically or horizontally integrated internationally ${ }^{2}$, and may vary from country to country as well as over time. Many cross-sectional studies for the US find a complementary relationship between exports and outward FDI in models of export demand with FDI included as an explanatory variable. Lipsey and Weiss (1981, 1984) in separate studies using industry-level and firm-level data for 1970, report a generally positive relationship between the output of US foreign affiliates in a country and US exports to that country, owing to an increased demand for intermediate goods. Evidence for the relationship between Sweden and the US, Blomstrom et al. (1988), also indicates a generally positive relationship between exports and outward FDI. Similar results have also been achieved for a greater number of countries, Veugelers (1991) for

\footnotetext{
2 Markusen (1995) in an imperfectly competitive framework with horizontally integrated MNEs predicts that exports and direct investment may become substitutes over time. Howerver, an alternative framework considering a vertically integrated firm with 'headquarter servies' (Helpman, 1984) can lead to an increase in exports as a result of FDI.
} 
all the OECD countries, and Hufbauer et al. (1994) for the US, Japan and Germany. There is also some evidence for OECD countries, Pain and Wakelin (1996), that FDI needs to be included in a model of export demand. Both outward and inward FDI were found to play an important role in explaining changes in trade shares for OECD countries. Outward FDI was generally found to have a negative relationship with exports (with some exceptions), while inward investment had led to increases in exports.

\section{The competitiveness of firms: Ownership advantages.}

In this paper we include a technological indicator based on the patents taken out by firms in each country in the US. This variable reflects not only the technological level of the country, but also the technological advantages of the firms within the country. Technology can be said to consist of two different aspects. The first can be captured by the firm, with innovation giving an ownership advantage to the firm which is firm specific, and which provide a basis for internalising transactions (Dunning, 1993). This may lead firms to prefer direct investment over arms-length transactions such as licensing. The second relates to the industry and country in which the firm is located and has been referred to as a national system of innovation, Lundvall (1992). These two aspects are interrelated; it is the former, the ownership advantages of the firm which may provide a basis for the firm becoming a MNE; and the latter which the MNE may seek out.

Other studies which have included proxies for innovation generally use either R\&D expenditures (Clegg 1987, Swedenborg 1979), R\&D intensities (Kogut and Chang 1991), or in some cases, the availability of skilled human capital (Papanastassiou and Pearce 1990). Fewer studies have attempted using output measures from the innovation process such as patenting. Cantwell (1989) utilised a comparative patenting advantage, while Narula (1996) attempted an absolute count of patents by home and host country on a per capita basis.

\section{The Empirical Model}

This paper aims to assess the determinants of bilateral US multinational activity in the manufacturing sector of seven industrialised countries. Multinational activity is taken to be a function of both the characteristics of the host country and of the home country, the USA. The determinants of US FDI included are demand in the host market, and cost differences between the host and the home market. In this case relative unit labour costs are used as the cost variable. This simple demand model is extended to include the 
relative technological capabilities of the home and host countries. Technological differences between countries have often been neglected as a determinant of FDI, but the rise of multinational activity between industrialised countries indicates that FDI is no longer undertaken with the sole motive of finding a lower cost location for production. In addition, exports to the host country from the home country are also included in order to examine the link between exports and FDI. The relationship estimated embodies a longrun relationship of the form given in Equation 1:

$$
\begin{array}{r}
\ln \left(\mathrm{FDI}_{\mathrm{usj}, \mathrm{t}}\right)=\alpha+\beta_{1} \ln \left(\text { Size }_{\mathrm{j}, \mathrm{t}}\right)+\beta_{2} \ln \left(\mathrm{Pat}_{\mathrm{us}, \mathrm{t}}\right)+\beta_{3} \ln \left(\mathrm{Pat}_{\mathrm{j}, \mathrm{t}}\right)+\beta_{4}\left(\operatorname{lnULC} \mathrm{C}_{\mathrm{j}, \mathrm{t}}-\ln \mathrm{lLC}_{\mathrm{us}, \mathrm{t}}\right) \\
+\beta_{5}\left(\ln \mathrm{X}_{\mathrm{usj}, \mathrm{t}}\right)+\beta_{6} \ln \left(\mathrm{ER}_{\mathrm{usj}, \mathrm{t}}\right)+\varepsilon_{\mathrm{t}}
\end{array}
$$

for $\mathrm{t}=1, \ldots . n$, where the subscripts $u s$ and $j$ are for the USA and the host country respectively. Seven host countries are considered; the UK, Germany, the Netherlands, France, Sweden, Italy and Japan. The dependent variable, the level of multinational activity in the host country, is measured as the stock of US direct investment in the manufacturing sector in each country $\mathrm{j}(\mathrm{FDI})^{3}$.

Size $_{\mathrm{j}}$ gives demand in the host country $\mathrm{j}$, and is proxied by the value added in manufacturing in the host country. The size of market demand is expected to positively influence the stock of FDI in the host country, as a large market provides greater domestic demand for the subsidiary firm. For some of the smaller EU countries, it may be the case that firms have access to a larger market than indicated by domestic value added, with the result that this variable does not mirror the true market size. As only the UK has entered the EU within the period under consideration, a dummy variable for EU entry is included for the UK, in order to capture the effect of an increase in market size during that period.

The technology variables for the home and host countries $\left(\mathrm{Pat}_{\mathrm{us}}, \mathrm{Pat}_{\mathrm{j}}\right)$ are included to reflect the role of innovation, and firm specific technological advantages, in influencing the investment behavior of MNEs. Multinational firms may be searching for technological advantages in the host countries in which they locate, particularly when they are investing in other industrialised countries. The unique national system of innovation of each country can give advantages to firms located in that country. In cases in which FDI is motivated by technological advantages, we would expect a positive coefficient on either the host or home country technology variable, or both.

\footnotetext{
3 The choice of US FDI stock data from the US department of commerce (see appendix) provides a better estimate of US multinational activity than other sources; it includes not just net flows from the US, but also reinvested earnings by the subsidiary.
} 
The difficulties involved in measuring technological capabilities directly prompts the need for a proxy for the technological capabilities of a country. The most common proxies used are $R \& D$ expenditure, which is an input into the innovation process, and the number of patents taken out by a country which are an output from the innovation process $^{4}$. For the latter to be internationally comparable the number of patents from each domestic patent system is not appropriate, and as a result a single country, generally the US, is used for comparison. As a large percentage of patents taken out in the US originate in foreign-based firms this provides a reflection of the technological capabilities of individual countries and as a result US patents have been widely used in economic studies (see Griliches, 1990, for a survey of their use). In this paper, technological capabilities are proxied by patents taken out in the US in the manufacturing sector $\left(\mathrm{Pat}_{\mathrm{us}}\right.$, Pat $_{\mathrm{j}}$ ); either by US companies, or companies based in the host countries.

Relative unit labour costs (ULC) are included in the model to indicate the cost advantages associated either with the home or host country. Relative unit labour costs are given by unit labour costs in manufacturing in the host country $\mathrm{j}$ relative to those in the US. Cheaper labour in the host country may be an incentive for MNEs to locate in that country. If lower costs are a motivating factor for FDI this will result in a negative coefficient on the relative unit labour costs variable, with lower costs in the host country relative to the US acting as an incentive for the location of production overseas. There is some evidence for the US, Barrell and Pain (1996), that outward direct investment is sensitive to rises in relative unit labour costs, with higher labour costs at home leading to an increase in FDI.

The relationship between exports and FDI has been the subject of much debate 5 . Lagged exports in manufacturing $(\mathrm{X})$ from the US to the host country are included in the model to investigate the relationship between the two. It is agreed that an export relationship between countries often precedes direct investment, indicating a positive relationship between past exports and FDI. However, the countries included in this sample have experienced high levels of inward FDI for a number of years, and that early relationship between trade from the US and FDI may no longer hold. When trade and FDI occur simultaneously the two may be substitutes, so that overseas location takes place instead of trade; or they may be complements, with FDI leading to increased exports from the home country (Cantwell, 1994). The coefficient on the lagged export variable could therefore be either negative or positive. There is also some evidence, Pfaffermayr (1994,

\footnotetext{
${ }^{4}$ Evidence from the US, Acs and Audretsch (1988), indicates a strong positive correlation between company R\&D expenditure, patents and actual innovations.

${ }^{5}$ See Pain and Wakelin (1996) for a review of both the theoretical and the empirical literature.
} 
1996) that at least in the case of Austria causation runs in both directions between exports and FDI. The potential endogeneity problem this produces is avoided by using lagged rather than contemporary exports, as past exports are clearly not caused by present FDI stocks.

As the time period covered by the data contains considerable exchange rate volatility, the bilateral exchange rate (ER) between the host country $\mathrm{j}$ and the US is also included as an explanatory variable. The exchange rate is given as domestic currency per US dollar. Some variation may occur in the dollar series for the host countries which is due to exchange rate variations with the dollar, rather than changes in the values of the domestically priced series. In cases where the exchange rate variable was not significant it was not included in the final estimation.

Data are available for each country annually from 1972 to 1991, i.e. 20 years, giving a total number of 140 observations in the panel. Due to lack of data the period ends in 1991, and as a result we do not have to deal with data problems associated with German reunification. Furthermore, by excluding data prior to 1972 we are also able to avoid the effects of the US capital control programme. The relative variables are on a bilateral basis between the USA and each of the seven host countries. All the variables are in logarithms in constant US dollar prices.

We initially treat the country data as a panel and estimate a dynamic version of Equation 1 in the form given below:

$$
\begin{aligned}
& \Delta \ln \left(\mathrm{FDI}_{\mathrm{usj}, \mathrm{t}}\right)=\alpha_{\mathrm{usj}}+\beta_{\text {lusj }} \ln \left(\operatorname{Size}_{\mathrm{j}, \mathrm{t}}\right)+\beta_{2 \mathrm{usj}} \ln \left(\operatorname{Size}_{\mathrm{j}, \mathrm{t}-1}\right)+\beta_{3 \mathrm{usj}} \ln \left(\mathrm{FDI}_{\mathrm{usj}, \mathrm{t}-1}\right)+\beta_{4 \mathrm{usj}} \ln \left(\mathrm{PAT}_{\mathrm{j}, \mathrm{t}-1}\right) \\
& \quad+\beta_{4 \mathrm{usj}} \ln \left(\mathrm{PAT}_{\mathrm{us}, \mathrm{t}-1}\right)+\beta_{5 \mathrm{usj}} \ln \left(\mathrm{ULC}_{\mathrm{jus}, \mathrm{t}}\right)+\beta_{6 u s j} \ln \left(\mathrm{X}_{\mathrm{usj}, \mathrm{t}-1}\right)+\beta_{7 \mathrm{usj}} \ln \left(\mathrm{ER}_{\mathrm{jus}, \mathrm{t}}\right)+\varepsilon_{\mathrm{usj}, \mathrm{t}}
\end{aligned}
$$

country-specific fixed effects were included to allow for effects which vary by country and which are not included in the model and which do not vary over time. This could, for instance, capture the benefit of the common language between the UK and the US which may have had a positive impact on the level of US FDI undertaken in the UK. The inclusion of fixed effects was not rejected using a likelihood ratio test.

\section{Results from the Model}

Treating the data as a panel requires the restrictive assumption of common parameters on all explanatory variables across countries. In order to test this restriction, the panel model with fixed effects was tested against an unrestricted model allowing all the coefficients to vary by country. The panel model was rejected $[\operatorname{LR}(42)=82.71]$ relative to the unrestricted model. Examining the results of the unrestricted model shows that the 
determinants of US FDI vary from country to country even among this sample of industrialised countries, and as a result common coefficients cannot be imposed. Due to this heterogeneity of determinants across countries, the model was applied on a country specific basis using OLS. The results are presented below in Table 2 for each country in turn, including the long-run parameters. Different lags are used for relative patents and exports in order to minimise possible serial correlation for each country.

As the two technology variables, patents in the home country and patents in the US, frequently have opposite coefficients, the hypothesis of equal and opposite coefficients is tested for each country. The hypothesis was only rejected in the case of the Netherlands (the Wald statistics for the test are given in Table 2). When the hypothesis was not rejected the two patent variables were replaced with a logged relative technology variable (Relpat ${ }_{j u s}$ ), giving patents in the home country $\mathrm{j}$ less those in the US. In the case of the Netherlands, the positive effect from domestic patenting is of a greater magnitude than the negative effect from US patenting, so the restriction of equal and opposite coefficients is rejected. As a result both patent variables are included together.

The signs on the technology variables fall into two groups. For one group of countries Germany, the Netherlands and Sweden - domestically produced patents, which represent the technological level of the host country, are positively related to FDI from the US, and FDI appears to be negatively related to the technology level of the US. For these countries it appears that the technological level of the host country relative to the US is a significant positive long-run determinant of US FDI; with firms seeking technological advantages in the countries in which they locate their subsidiaries.

The second group of countries, comprising the UK, France and Japan, shows the inverse relationship; with relative patenting having a significant negative long-run relationship with US FDI. For these three countries the technological level of the US appears to play a 
Table 2

Dependent Variable: $\triangle$ FDI

Estimation Period: 1972-1991

\begin{tabular}{|c|c|c|c|c|}
\hline & UK & Germany & France & Italy \\
\hline $\mathrm{c}$ & $-18.55(3.10)$ & $29.21(2.46)$ & $-41.60(2.58)$ & $-10.50(0.99)$ \\
\hline $\mathrm{FDI}_{-1}$ & $-0.90(5.38)$ & $-1.32(6.77)$ & $-0.42(3.90)$ & $-0.45(2.02)$ \\
\hline$\Delta$ SIZE & $1.05(3.76)$ & $0.28(0.70)$ & $1.23(2.09)$ & $1.07(2.98)$ \\
\hline SIZE $_{-1}$ & $1.36(4.20)$ & $-0.69(1.50)$ & $1.86(2.90)$ & $0.64(1.43)$ \\
\hline RELPAT $_{-1}$ & & $0.70(4.46)$ & & $0.12(0.52)$ \\
\hline${\overline{\text { RELPAT }_{-2}}}$ & $-0.97(3.22)$ & & $-1.19(4.01)$ & \\
\hline ULC & $-0.26(2.14)$ & $-0.45(4.39)$ & $1.54(6.91)$ & $-0.08(0.73)$ \\
\hline $\mathrm{X}_{-1}$ & $-0.58(5.25)$ & & $-0.56(4.83)$ & $-0.08(0.86)$ \\
\hline $\mathrm{X}_{-2}$ & & $0.17(2.61)$ & & \\
\hline ER & & & $1.78(6.30)$ & \\
\hline \multicolumn{5}{|c|}{ Diagnostic statistics } \\
\hline$\overline{\overline{R^{2}}}$ & 0.71 & 0.76 & 0.83 & 0.75 \\
\hline SE & 0.05 & 0.05 & 0.04 & 0.06 \\
\hline LM [Chi(2)] & $2.73[0.10]$ & $0.09[0.76]$ & $0.44[0.51]$ & $0.36[0.55]$ \\
\hline $\mathrm{BJ}[\mathrm{Chi}(2)]$ & $0.59[0.75]$ & $0.09[0.96]$ & $1.23[0.54]$ & $0.16[0.92]$ \\
\hline Hetero [Chi(1)] & $0.01[0.92]$ & $1.37[0.24]$ & $0.002[0.96]$ & $1.18[0.28]$ \\
\hline \multicolumn{5}{|c|}{ Test of restriction on Patents } \\
\hline Wald Statistic & $0.06[0.80]$ & $3.15[0.08]$ & $1.97[0.16]$ & $0.001[0.97]$ \\
\hline \multicolumn{5}{|c|}{ Long-run parameters } \\
\hline SIZE $_{-1}$ & $1.52(6.70)$ & $-0.52(1.46)$ & $4.48(2.50)$ & $1.43(1.35)$ \\
\hline RELPAT $_{-1}$ & & $0.53(5.01)$ & & $0.26(0.51)$ \\
\hline RELPAT $_{-2}$ & $-1.08(3.09)$ & & $-2.87(2.98)$ & \\
\hline ULC & $-0.29(2.59)$ & $-0.33(6.18)$ & $3.71(3.54)$ & $-0.18(0.61)$ \\
\hline $\mathrm{X}_{-1}$ & $-0.64(5.37)$ & & $-1.36(3.21)$ & $-0.18(0.77)$ \\
\hline $\mathrm{X}_{-2}$ & & $0.13(2.95)$ & & \\
\hline ER & & & $4.27(3.43)$ & \\
\hline
\end{tabular}

Notes: t-statistics in parentheses for parameters, p-values in parentheses for test statistics. 
Table 2 continued

Dependent Variable: $\triangle$ FDI

Estimation Period 1972-1991

\begin{tabular}{|c|c|c|c|}
\hline & Netherlands & Japan & Sweden \\
\hline $\mathrm{c}$ & $-7.50(0.67)$ & $-53.87(4.42)$ & $-23.53(3.65)$ \\
\hline $\mathrm{FDI}_{-1}$ & $-1.02(5.51)$ & $-0.88(4.51)$ & $-0.68(3.97)$ \\
\hline$\Delta$ SIZE & $0.57(1.26)$ & $1.87(3.44)$ & $-1.36(3.37)$ \\
\hline SIZE $_{-1}$ & & $2.67(5.05)$ & $1.09(3.61)$ \\
\hline $\mathrm{SIZE}_{-2}$ & $0.67(1.36)$ & & \\
\hline RELPAT $_{-1}$ & & & $0.48(5.06)$ \\
\hline RELPAT $_{-2}$ & & $-0.53(2.86)$ & \\
\hline $\mathrm{PATNL}_{-1}$ & $0.64(3.17)$ & & \\
\hline PATUS $_{-1}$ & $-0.29(1.74)$ & & \\
\hline ULC & $-0.39(3.22)$ & $-0.28(2.02)$ & $0.16(1.48)$ \\
\hline $\mathrm{X}_{-1}$ & $-0.05(0.37)$ & $-0.55(3.39)$ & $0.01(0.18)$ \\
\hline \multicolumn{4}{|c|}{ Diagnostic statistics } \\
\hline$\overline{R^{2}}$ & 0.76 & 0.67 & 0.88 \\
\hline $\mathrm{SE}$ & 0.05 & 0.08 & 0.04 \\
\hline LM [Chi(2)] & $1.33[0.25]$ & $0.12[0.72]$ & $0.01[0.94]$ \\
\hline $\mathrm{BJ}[\mathrm{Chi}(2)]$ & $1.01[0.60]$ & $1.66[0.43]$ & $0.77[0.68]$ \\
\hline Hetero [Chi(1)] & $0.18[0.67]$ & $0.01[0.92]$ & $0.75[0.39]$ \\
\hline \multicolumn{4}{|c|}{ Test of restriction on Patents } \\
\hline Wald Statistic & $7.10[0.01]$ & $1.50[0.22]$ & $0.42[0.51]$ \\
\hline \multicolumn{4}{|c|}{ Long-run parameters } \\
\hline $\mathrm{SIZE}_{-1}$ & & $3.02(6.08)$ & $1.60(2.86)$ \\
\hline SIZE $_{-2}$ & $0.66(1.50)$ & & \\
\hline RELPAT $_{-1}$ & & & $0.70(4.54)$ \\
\hline RELPAT $_{-2}$ & & $-0.06(3.63)$ & \\
\hline $\mathrm{PATNL}_{-1}$ & $0.62(2.64)$ & & \\
\hline PATUS $_{-1}$ & $-0.28(1.52)$ & & \\
\hline ULC & $-0.38(3.21)$ & $-0.32(1.99)$ & $0.23(1.93)$ \\
\hline$\overline{X_{-1}}$ & $-0.05(0.35)$ & $-0.62(2.63)$ & $0.01(0.18)$ \\
\hline
\end{tabular}


positive role in promoting FDI, while the domestic technological level of the host countries does not act as an incentive for FDI. In this case US firms may be building on firm specific innovation advantages, rather than seeking technological advantages in the countries in which they locate.

The size of the relative patent effects also vary by country. The largest negative effects are found for France, with a long-run elasticity of greater than 2, and the UK. In general the positive long-run elasticities from relative patents are of a smaller magnitude, with the three other countries having elasticities between 0.5 and unity. For only one country, Italy, is the technology variable not significant, indicating the importance of technology as a determinant of FDI.

The coefficients on the domestic market demand variable (Size) are generally positive and significant as expected. In only three cases, Italy, the Netherlands and Germany are the coefficients not significant, and for Germany the coefficient is actually negative. As mentioned earlier it could be that market demand is no longer limited to the domestic market, but is rather given by the market in the EU as a whole for member countries. However, when a dummy variable for EU membership is included in the model for the UK it is found to be insignificant. Two different dummies were used, the first took a value of one after 1973, when the UK joined the EEC, and the second after 1977 when the UK conformed to the single common external tariff. Neither was found to be significant. In general, however, large and significant demand effects were found.

The results from the relative unit labour cost variable (ULC) also conform to expectations. For four countries, the UK, Germany, the Netherlands and Japan, lower unit labour costs in the host country relative to the US act as an incentive to FDI. It is interesting to note that only for Germany does this negative and significant relationship between relative labour costs and FDI coexist with a positive relationship between the technology level of Germany and FDI. The other countries, appear to be attractive locations for FDI due to lower relative labour costs rather than the technology level of the country, while for Germany it is both these factors.

The long-run elasticities on the relative unit labour cost variable (with the exception of France) are lower than those found in Barrell and Pain (1996) ${ }^{6}$. They found a long-run elasticity of around 0.5 when considering US FDI with the whole world. This implies that investment in OECD countries is less sensitive to cost differences than investment in all host countries including developing countries. US investment in other developed countries may be motivated by factors such as differences in technology, and strategic

6 They also included a relative user cost of capital variable, but did not include relative technology levels. 
considerations making the investment decisions less sensitive to differences in labour costs.

France, on the other hand, has a positive relationship between relative unit labour costs and FDI. This indicates that higher relative wages in France have not acted as a disincentive to FDI. One possible explanation for this seemingly paradoxical result is the lack of a human capital variable in the model. Higher relative wages in France may be reflecting a higher level of skills which is acting as an incentive to MNEs. Unfortunately data limitations make building a satisfactory cross-country proxy for human capital or skills highly problematic ${ }^{7}$.

One relationship which is of particular interest in this model is that between lagged exports and FDI. As the results in Table 2 show there is some variation in the results across countries. Three of the seven countries in the sample show a significant negative long-run relationship between lagged exports and FDI; they are the UK, France and Japan. One country - Germany - shows a significant positive long-run relationship between exports and FDI. For the other three countries, Italy, the Netherlands and Sweden, the relationship is not significant. The negative relationship found for three of the countries indicates that in those countries FDI is now substituting for exports, while in the case of Germany exports and FDI are complementary, and for the other countries there is no significant relationship between the two. One explanation for these different results is that the nature of US direct investment in Japan, France and the UK may be different from investment in Germany, involving horizontally rather than vertically integrated firms. Another is that this model considered only FDI in the manufacturing sector. There is some evidence for the US (Lipsey and Weiss, 1981 and Yamawaki, 1991a, for the US and Japan) that investment in non-manufacturing affiliates leads to an improvement in export performance as these provide services which are complementary to exports. So it is not clear from these results that total FDI, including FDI in nonmanufacturing would have the same relationship with exports.

The magnitude of the negative long-run elasticities on the lagged export variable also vary across countries. In some cases the elasticity is very high, in particular for France where it is greater than unity. The negative elasticities for the UK and Japan are also relatively high, while the positive long-run elasticity for Germany is much lower.

\footnotetext{
7 Those human capital variables which are available, such as the average number of years of schooling, seem inappropriate for this group of countries, as there is very little variation in this variable over the period being considered for most OECD countries.
} 
Finally, the exchange rate variable was significant only in the model for France in which it was positively related to FDI. A positive relationship indicates that the dollar strengthening against the French Franc led to an increase in FDI from the US to France, as we would expect. This sensitivity to the exchange rate appears to have existed only in the case of France, as the variable was not significant in the other models.

\section{Summary and Conclusions}

A number of points emerge from the empirical analysis. The first is that the determinants of US FDI vary considerably according to the host country, even within this sample of seven industrialised countries. For some countries, such as the UK and Japan, the technological advantages of the US, and the lower relative wages of the host country, seem to be the determining factors influencing US FDI. For other countries, such as Germany and France, different combinations of determinants are significant. For Germany it appears to be a combination of the technological assets of Germany relative to the US, lower relative unit labour costs, and past exports. This heterogeneity is indicated by the rejection of the panel model imposing common coefficients across countries.

The basic demand model gives the expected results. Market size has a generally positive and significant effect on inward FDI, relative unit labour costs have a generally negative effect, with the exception of France. Lower unit labour costs in the host countries relative to the US appear to act as an incentive for FDI. However, the size of this effect is small, with a $1 \%$ rise in relative costs in the host country reducing inward FDI by between $0.38 \%$ and $0.18 \%$ in the long run. These effects are generally smaller than those from relative technology, or from lagged exports. It should also be remembered that the variation in relative costs between the group of sample countries and the US is small in comparison to the cost differences between the US and other less industrialised countries.

The additional variables included in the model, namely the technology variables and lagged exports, play an important role in explaining US FDI. Either the two country technology variables, or relative technology, are significant for all countries apart from Italy; in a number of cases the elasticities are large, indicating an important role for technology in influencing FDI. While technology appears to be important for almost all countries in the sample, the influence of the technology variables for the home and host countries falls into two groups. For one group of countries it is the technological assets of the home country which has a positive influence on FDI; for the other group of countries it is those of the host country. Therefore the direction of impact of the technology 
variables is not the same across countries, but the significance of the variable is considerable within this sample of countries.

The role of lagged exports also varies by countries, in three cases exports and FDI appear to be substitutes, while for Germany they are complements. The coefficients show that the size of this effect can also be quite large. The results indicate that the effect of outward FDI on US exports is not neccessarily clear cut. While outward FDI to some of the countries has acted as a substitute for exports, in the case of Germany FDI has led to increased exports from the US to Germany. It is therefore difficult to assess the impact on US production and the balance of trade.

The results indicate that there is no one factor required to attract FDI from the US. It appears that the motives for FDI in manufacturing, and the nature of the FDI vary considerably from country to country. There is no single set of characteristics which make a country 'competitive' as a location for inward investment, and the impact of outward investment on the home country in terms of exports also depends on the country. However, it should be kept in mind that policies to attract FDI were not included in the model. These can be quite substantial. For instance the Mercedes Benz plant in Alabama, USA, attracted US\$250 million in direct incentives on an initial investment of US\$ 300 million (UNCTAD 1995). If government incentives are importat in influencing inward FDI then they need to be included in future work. 


\section{Appendix: Data and sources}

\begin{tabular}{|c|c|c|}
\hline Variable & Description & Source \\
\hline FDI & $\begin{array}{l}\text { The stock of US outward FDI in } \\
\text { constant } 1985 \$ \text { prices. } \\
\text { It includes reinvested earnings, } \\
\text { equity and intercompany account } \\
\text { outflows. }\end{array}$ & $\begin{array}{l}\text { Survey of Current } \\
\text { Business, } \\
\text { various editions }\end{array}$ \\
\hline$\Delta \operatorname{lnFDI}$ & $\operatorname{lnFDI}-\operatorname{lnFDI} I_{-1}$ & \\
\hline SIZE & $\begin{array}{l}\text { Value added in the US in } 1985 \$ \\
\text { prices }\end{array}$ & OECD STAN database \\
\hline$\Delta \operatorname{lnSIZE}$ & $\operatorname{lnSIZE}-\ln \mathrm{SIZE}_{-1}$ & \\
\hline $\mathbf{P A T}_{\mathbf{u s}}, \mathbf{P A T}_{\mathbf{j}}$ & $\begin{array}{l}\text { number of patents granted in the } \\
\text { US to country } j \text {, date of grant, } \\
\text { fractional count }\end{array}$ & OECD STAN database \\
\hline InRELPAT & $\operatorname{lnPat}{ }_{j}-\ln P a t_{u s}$ & \\
\hline ULC & $\begin{array}{l}\text { Unit labour costs in US } \$ \text {, calculated } \\
\text { by dividing total labour costs (in } \\
\text { local currency, divided by relevant } \\
\text { exchange rate) by value added in } \\
1985 \text { prices (divided by } 1985 \\
\text { exchange rate) }\end{array}$ & OECD STAN database \\
\hline $\mathbf{X}$ & $\begin{array}{l}\text { manufacturing exports from US to } \\
\text { host country j in } 1985 \text { dollar prices }\end{array}$ & OECD STAN database \\
\hline ER & Domestic currency per US\$ & OECD STAN database \\
\hline
\end{tabular}




\section{References}

Acs, Z.J. and Audretsch, D.B. (1988), 'Innovation in large and small firms: an empirical analysis', American Economic Review, 78, 678-690.

Agarwal, J. (1980) 'Determinants of foreign direct investment: a survey', Weltwirtschaftliches Archiv, Vol 116, 739-73

Barrell, R. and Pain, N. (1996), An Econometric analysis of US foreign direct investment, Review of economics and Statistics, Vol. 78(2).

Blomström, M., Lipsey, R.E. and Kulchycky, K. (1988), 'U.S. and Swedish direct investments and exports' in Trade Policy Issues and Empirical Analysis (ed. R.E.Baldwin), Chicago: University of Chicago Press.

Cantwell, J. (1989)Technological Innovation and Multinational Corporations, Basil Blackwell, Oxford

Cantwell, J.A. (1994) 'The relationship between international trade and international production' in Surveys in International Trade (eds. D.Greenaway and L.A.Winters), Oxford: Basil Blackwell.

Caves, R. (1996) Multinational Enterprise and Economic Analysis, 2nd edition, Cambridge University Press

Clegg, Jeremy (1987) Multinational Enterprises and World Competition London, Macmillan Press

Clegg, Jeremy (1996) 'US foreign direct investment in the EU - The effects of market integration in perspective' in F.Burton, M. Yamin and S. Young (eds) International Business and Europe in Transition, London, Macmillan Press

Culem, Claudy (1988) 'The locational determinants of direct investments among industrialized countries, European Economic Review,' Vol 32, pp 885-904

Dunning, J.H. (1993) 'Multinational enterprises and the global economy' Wokingham, Berks: Addison-Wesley.

Dunning, J.H. and Narula, R. (1997) 'Developing countries versus multinationals in a globalising world: the dangers of falling behind', in P. Buckley and P. Ghauri (eds), Multinational enterprises and emerging markets, London: Dryden Press.

Froot, K.and Stein, J. (1991) 'Exchange rates and foreign direct investment: An imperfect capital markets approach, Quarterly Journal of Economics, Vol 106, 1191-1217

Griliches, Z. (1990), 'Patent Statistics as Economic Indicators: a Survey', Journal of Economic Literature, 28.

Hagedoorn, J. and Narula R. (1996) 'Evolutionary Understanding of Corporate Foreign Investment Behaviour,: US Foreign Direct Investment in Europe’ MERIT Working Paper Series, 96-005

Helpman, E. (1984), 'A simple theory of international trade with multinational corporations', Journal of Political Economy, 92, 451-472. 
Hufbauer, G., Lakdawalla, D. and Malani, A. (1994), 'Determinants of direct foreign investment and its connection to trade', UNCTAD Review, 0(0), 39-51.

Kogut, B. (1983) 'Foreign direct investment as a sequential process', in Kindleberger, C. and Audresch, D. (eds), The Multinational Corporation in the 1980s, Cambridge, MIT Press

Kogut, B. and Chang S. (1996) 'Platform investments and volatile exchange rates: direct investments in the US by Japanese electronic companies' Review of Economics and Statistics, Vol 78, pp 221-231

Kogut, B. and Chang S. (1991) 'Technological capabilities and Japanese direct investment in the United States' Review of Economics and Statistics, Vol 73, pp 401413

Knickerbocker, F.T. (1973)Oligopolistic Reaction and the Multinational Enterprise. Cambridge, MA.: Harvard University Press

Lall, S. (1980) 'Monopolistic advantages and foreign involvement by US manufacturing industry', Oxford Economic Papers, Vol 32, 102-22

Lipsey, R.E. and Weiss, M.Y. (1981), 'Foreign production and exports in manufacturing industries', Review of Economics and Statistics, 63, 488-94.

Lipsey, R.E. and Weiss, M.Y. (1984), 'Foreign production and exports of individual firms', Review of Economics and Statistics, 66, 304-8.

Lunn, J. (1980) Determinants of US direct investment in the EEC, European Economic Review, Vol 13, pp 93-101

Lunn, J. (1983) Determinants of US direct investment in the EEC revisited again, European Economic Review, Vol 21, pp 391-393

Lundvall, B.A. Ed. (1992) National systems of innovation: towards a theory of innovation and interactive learning, Pinter: London.

Markusen, J.R. (1995). 'The boundaries of multinational enterprises and the theory of international trade.' Journal of Economic Perspectives, 9, 169-189.

Narula, R. (1996) Multinational Investment and Economic Structure, Routledge, London

Narula, R. and Wakelin, K. (1995) Technological competitiveness, Trade and Foreign direct investment, MERIT working paper 2/95-019.

Pain, N. and Wakelin, K. (1996) 'Foreign direct investment and export performance', paper presented at the 23rd EARIE conference, Vienna, September 1996.

Papanastassiou, M. and Pearce, R. (1990) Host Country Characteristics and the Sourcing Behaviour of the UK Manufacturing Industry, University of Reading Discussion Papers in International Investment and Business Studies, Series B, Vol II, No. 140

Pfaffermayr, M. (1994), 'Foreign direct investment and exports: a time series approach', Applied Economics, 26, 337-351. 
Pfaffermayr, M. (1996), 'Foreign outward direct investment and exports in Austrian manufacturing: Substitutes or Complements?', Weltwirtschaftliches Archiv, 132.

Scaperlanda, A, and Mauer, J. (1969) The determinants of US direct investment in the EEC, American Economic Review, 59, 558-68

Scaperlanda, A, and Balough, R. (1983) The determinants of US direct investment in the EEU: revisited, European Economic Review, 21, pp 381-90

Swedenborg, B. (1979) The Multinational Operations of Swedish Firms, The Industrial Institute for Economic and Social Research, Stockholm

UNCTAD (1996) World Investment Report 1996, United Nations, Geneva

UNCTAD (1995) World Investment Report 1995, United Nations, Geneva

Veugelers, R. (1991), 'Locational determinants and ranking of host countries: an empirical assessment', Kyklos, 44(3), 363-382.

Yamawaki, H. (1991a), 'Exports and foreign distributional activities: evidence on Japanese firms in the United States', Review of Economics and Statistics, 73(2), 294300.

Yamawaki, H. (1991b) 'Location decisions of Japanese multinational firms in European manufacturing industries' Catholic University of Leuven, mimeo.

Yu, J (1990) The experience effect and foreign direct investment, Weltwirtschaftliches Archiv, vol. 126, pp. 561-579. 